\title{
Uptake of dissolved inorganic nitrogen in turbid, tidal estuaries
}

\author{
Jack J. Middelburg*, Joop Nieuwenhuize \\ Netherlands Institute of Ecology, Centre for Estuarine and Coastal Ecology, PO Box 140, 4400 AC Yerseke, \\ The Netherlands
}

\begin{abstract}
Ammonium and nitrate uptake was measured in 6 European tidal estuaries (Ems, Rhine, Scheldt, Loire, Gironde and Douro) using ${ }^{15} \mathrm{~N}$-tracer techniques. Uptake rates of ammonium and nitrate

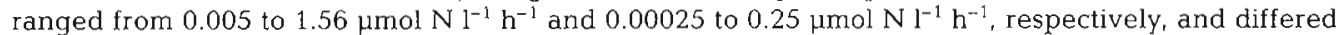
significantly between and within estuaries. Analysis of nitrogen uptake using the relative preferential index (RPI) indicated ammonium to be the preferred substrate. The turnover times of particulate nitrogen $(0.7$ to $31 \mathrm{~d})$ and dissolved ammonium $(0.1$ to $27 \mathrm{~d})$ were similar to or shorter than estuarine-water residence times, whereas turnover times of dissolved nitrate (19 to $2160 \mathrm{~d}$ ) were longer than residence times. Assimilation of nitrate in the water column of estuaries consequently does not influence its distribution, and most nitrate entering or produced in estuaries flushes through unless significant denitrification and/or burial in the sediment occur. As ammonium and particulate nitrogen are efficiently recycled, most allochthonous organic matter is extensively microbially modified before export, burial, or consumption by higher trophic levels.
\end{abstract}

KEY WORDS: Nitrogen uptake $\cdot$ Nitrogen turnover $\cdot$ Ammonium $\cdot$ Nitrate $\cdot$ Estuary $\cdot$ Heterotrophy

\section{INTRODUCTION}

Riverine concentrations of dissolved inorganic nitrogen (DIN) have been increased significantly by human activity, in particular in densely populated areas of Northern Europe and North America. Anthropogenic inputs of nitrogen to rivers arise primarily from fertilisers, atmospheric deposition in drainage basins and direct sewage discharge (Howarth et al. 1996). Enhanced riverine nitrogen inputs to estuaries and coastal seas may affect nitrogen cycling in these ecosystems, and, hence, their functioning. Documented disturbances include estuarine and coastal eutrophication, changes in phytoplankton community structure, and enhanced production and release of nitrous oxide (Jickells 1998).

Riverine DIN fluxes to the coastal zone are usually depleted during transit through estuaries, mainly through denitrification and burial in sediments (Nixon

•E-mail: middelburg@cemo.nioo.knaw.nl et al. 1996). Consequently, removal of DIN from estuaries through sedimentary denitrification and burial depends strongly on the transfer efficiency from DIN to sinking particulate organic nitrogen. Phytoplankton is a major agent of DIN conversion into biomass. However, estuaries are generally heterotrophic systems, with overall respiration (mainly bacterial) exceeding primary production (Heip et al. 1995, Gattuso et al. 1998). Since bacteria generally have a lower $C: N$ ratio than algae, it is likely that they contribute to DIN assimilation also. Wheeler \& Kirchman (1986) and Hoch \& Kirchman (1995) demonstrated the importance of ammonium uptake by heterotrophic bacteria.

Uptake of DIN (ammonium and nitrate) is usually measured by the incorporation of their ${ }^{15} \mathrm{~N}$-labelled salts into the filterable particulate fraction (Dugdale \& Wilkerson 1986). This technique has been applied to Chesapeake Bay (McCarthy et al. 1977, Fisher et al. 1992), the Neuse River Estuary (Boyer et al. 1994), Delaware Estuary (Pennock 1987), New York Bight (Garside 1981), Carmans River estuary (Carpenter \& Dunham 1985), Oslo fjord (Paasche \& Kristiansen 
1982), and the Humber estuary (Shaw et al. 1998) (see Underwood \& Kromkamp [1999] for a recent review of this approach in estuarine investigations). These studies revealed that, despite high nitrate concentrations, ammonium is generally the preferred nutrient, and reported high rates of ammonium uptake in the dark and high DIN turnover rates.

This study presents rates of ammonium and nitrate uptake and concentrations of ammonium, nitrate and particulate nitrogen in 6 tidal estuaries: the Ems, Scheldt, Loire, Gironde and Douro estuaries were investigated during the summer, and the Rhine estuary was studied during spring, autumn and summer. These estuaries cover a wide range of suspended-matter concentrations, DIN concentrations and water residence times. Our objectives were (1) to test whether DIN uptake in these turbid European tidal estuaries conforms to the observations reported in the literature, and (2) to compare the turnover times of nitrogen pools in estuarine waters with the water residence times.

\section{MATERIAL AND METHODS}

Study areas. The estuaries investigated are situated along the European Atlantic coast and cover a northsouth gradient (Fig 1). Physical characteristics of the estuaries are summarised in Table 1. Estuarine-water residence times are either based on literature information (Ems, Scheldt, Gironde, Loire: Relexans et al. 1988, Heip \& Herman 1995, Soetaert \& Herman 1995), or have been estimated from water volume and riverdischarge data (Rhine and Duoro). The Ems estuary (The Netherlands, Germany) connects the northeast-

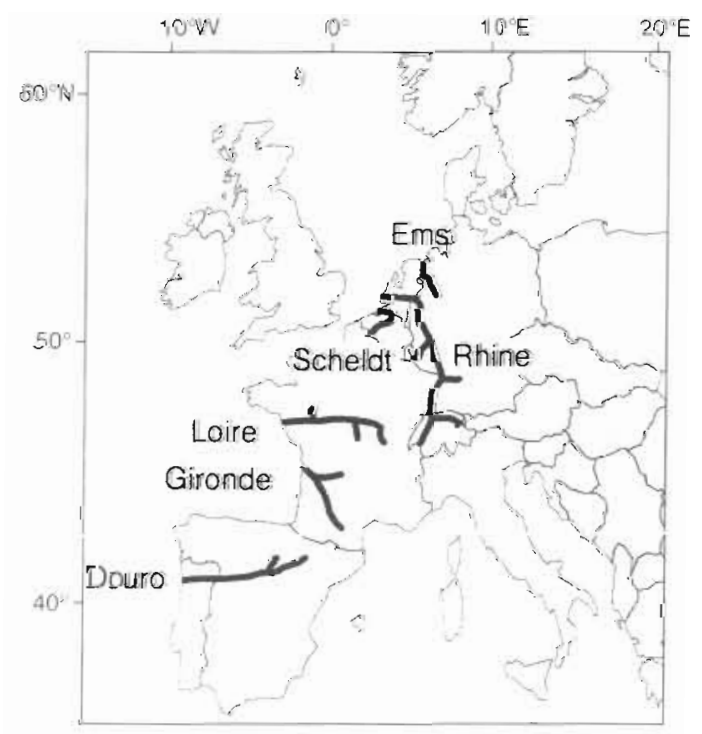

Fig. 1. Geographic location of investigated estuaries ern part of The Netherlands and the northwestern part of Germany with the North Sea. It is a typical wellmixed tidal estuary, with long residence times and high concentrations of suspended particulate matter (SPM). There are large intertidal flats in the lower (the Wadden Sea) and middle reaches (Dollard) that cover $\sim 50 \%$ of the total surface area. The drainage basin of the river Rhine covers large areas of Switzerland, Germany and The Netherlands, and smaller areas of Austria, France, Luxembourg and Belgium. The major part of Rhine water is discharged into the North Sea through the Nieuwe Waterweg, a typical river-dominated, salt-wedge estuary with a short water residence time and no tidal flats. The river Scheldt, which drains western Belgium and parts of Northwest France and Southwest Netherlands, feeds the Scheldt estuary, a well-mixed estuary with a long water residence time. The river Loire drains a major part of central France, and its estuary is well-mixed and very turbid, with SPM concentrations of $>1 \mathrm{~g} \mathrm{l}^{-1}$ The rivers Garonne and Dordogne that drain a large part of southwestern France feed the Gironde estuary, which is a wellmixed, highly turbid estuary with SPM concentrations of $>1 \mathrm{~g} \mathrm{l}^{-1}$. The river Douro drains large areas of northern Portugal and Spain before it flows into the Atlantic Ocean near the city of Port. It is a typical salt-wedge type estuary with a short water residence time. The drainage basins of the rivers Rhine and Scheldt are the most densely populated, and their DIN loading per unit surface area is consequently highest (Table 1). DIN export by the Ems and Gironde is intermediate, and that by the Loire and Douro is relatively low, but still significantly higher than that of the majority of the world's rivers (<1 to $1564 \mathrm{~kg} \mathrm{~N} \mathrm{~km}^{-2} \mathrm{yr}^{-1}$; Seitzinger \& Kroeze 1998).

Sampling. Water samples were collected in the context of BIOGEST, a EU-supported programme on biogeochemical processes and trace-gas production in a number of European tidal estuaries. Samples were taken along the spines of the estuaries at selected salinity intervals during campaigns typically lasting 3 to $5 \mathrm{~d}$. The Ems, Scheldt, Loire, Gironde and Douro estuaries were studied during June/July 1997, June 1998, September 1998, June 1997, and September 1997, respectively. The Rhine estuary was sampled 3 times, in July 1997. November 1997 and April 1998. Surface water $(<2 \mathrm{~m}$ depth) samples were collected in $20 \mathrm{l}$ Niskin bottles and subsampled within $10 \mathrm{~min}$.


because of the polluted nature of these estuaries (Frankignoulle et al. 1996).

Concentration measurements. Water samples were filtered immediately through pre-weighted, pre-combusted glass fibre filters (GF/F, Whatman), stored frozen, and analysed within 2 wk for ammonium, 
Table 1. Physical characteristics of investigated estuaries

\begin{tabular}{|c|c|c|c|c|c|c|c|}
\hline Estuary & $\begin{array}{l}\text { Area } \\
\left(\mathrm{km}^{2}\right)\end{array}$ & $\begin{array}{c}\text { Drainage } \\
\text { basin } \\
\left(10^{3} \mathrm{~km}^{2}\right)\end{array}$ & $\begin{array}{l}\text { Discharge } \\
\left(\mathrm{km}^{3} \mathrm{yr}^{-1}\right)\end{array}$ & $\begin{array}{l}\text { Water } \\
\text { residence } \\
\text { (d) }\end{array}$ & $\begin{array}{l}\text { Tidal } \\
\text { range } \\
(\mathrm{m})\end{array}$ & 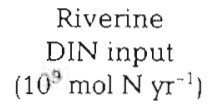 & $\begin{array}{c}\text { DIN export } \\
\text { watershed } \\
\left(\mathrm{kg} \mathrm{N} \mathrm{km}^{-2} \mathrm{yr}^{-1}\right)\end{array}$ \\
\hline Ems & 162 & 13 & 2.5 & $14-70$ & $2-3$ & 0.71 & 770 \\
\hline Scheldt & 269 & 22 & 4 & $30-90$ & $2-5$ & 1.8 & 1170 \\
\hline Loire & 41 & 121 & 27 & $1-10$ & $3-6$ & 1.5 & 175 \\
\hline Gironde & 442 & 85 & 21 & $20-70$ & $3-5$ & 2.9 & 485 \\
\hline Douro & 2.4 & 98 & 20 & \pm 2 & $1-3$ & 1.5 & 214 \\
\hline Rhine & 71 & 224 & 70 & \pm 2 & $2-3$ & 21 & 1310 \\
\hline
\end{tabular}

nitrate and nitrite using automated colorimetric techniques. Material on filters was weighted and used for analyses of particulate nitrogen and carbon with a Carlo Erba NA 1500 elemental analyser (Nieuwenhuize et al. 1994).

DIN uptake rates. Water samples were spiked with ${ }^{15} \mathrm{NH}_{4}$ or ${ }^{15} \mathrm{NO}_{3}$ at $<10 \%$ of ambient concentrations, and were incubated in $250 \mathrm{ml}$ bottles in on-deck incubators with running estuarine water. Incubations lasted $-2 h_{1}$ and were performed both in the dark and under ambient light on the deck of the ship. ${ }^{15} \mathrm{~N}$ incubations were halted by filtration of sample through pre-combusted Whatman GF/F filters $(20 \mathrm{~mm})$. The filters were immediately placed in aluminium foil and stored frozen.

The at. $\%{ }^{15} \mathrm{~N}$ of freeze-dried filters was determined with a Fisons NA 1500 elemental analyser coupled to a Finnigan Delta $S$ mass spectrometer via a Conflo II interface. Specific uptake rate $\left(V, \mathrm{~h}^{-1}\right)$ was calculated according to Dugdale \& Wilkerson (1986), and was multiplied by the independently measured particulatenitrogen concentration (PN) to obtain the transport or absolute uptake rate, $U$ ( $\mu$ mol $\left.\mathrm{N}^{-1} \mathrm{~h}^{-1}\right)$. Uptake rates were corrected for isotope-dilution by the model of Kanda et al. (1987), whereby regeneration equalled uptake.

During sample-processing, the questions of isotopic exchange in high-turbidity samples and the contribution of bacterial assimilation to total ammonium uptake arose. A broad-spectrum antibiotic (penicillin-G, streptomycin and neomycin: SIGMA, P3664), a cellgrowth inhibitor of Gram-positive and Gram-negative bacteria, was therefore added to samples from the Loire estuary, the estuary last investigated. The antibiotic was added $2 \mathrm{~h}$ before the ${ }^{15} \mathrm{NH}_{4}$ tracer at a final concentration of $10 \mathrm{mg} \mathrm{l}^{-1}$.

Data analysis. The depth of the euphotic zone $\left(Z_{\mathrm{eu}}\right)$ is based on the relation $Z_{\text {eu }}=-\ln (0.01) / k$. The light extinction coefficient $\left(k, \mathrm{~m}^{-1}\right)$ was calculated from SPM concentrations as: $k=0.59+0.038 \times$ SPM (Soetaert et al. 1994). Analysis of variance (ANOVA), based on logtransformed data, was used to evaluate significant dif- ferences in uptake rates. Variability within estuaries was assessed by partitioning the estuaries according to salinity: upper (0 to 10$)$, middle (10 to 20 ) and lower $(>20)$. The median was chosen as the nonparametric statistic of comparison between dark/light uptake because most of the data were skewed towards larger values. Correlation analysis of uptake rates and salinity, euphotic-zone depth and nutrient concentrations revealed relationships for the mean of light and dark uptake similar to those for the independent uptake rates. The mean of the light/dark incubations is therefore presented in Figs, 2 to 5, thus reducing the number of figures with minimal loss of information.

\section{RESULTS}

\section{Dissolved inorganic nitrogen concentrations}

The estuarine distributions of dissolved ammonium and nitrate are shown in Fig. 2, their ranges are listed in Table 2 . There were significant variations between and within estuaries. Concentrations of total dissolved inorganic nitrogen were highest in the Ems, Scheldt, and Rhine estuaries, intermediate in the Gironde estuary, and lowest in the Loire and Douro estuaries. Nitrate concentrations were usually 1 order of magnitude higher than those of ammonium, except in the river Scheldt and the marine end-member portions of the Ems, Rhine and Loire estuaries, where they were about equal (Fig. 2).

Ammonium concentrations in the Loire, Gironde, Douro, and Rhine estuaries displayed no systematic relationship with salinity. The high concentrations of ammonium entering the Scheldt estuary decreased in a non-linear manner with increasing salinity because of ammonium consumption (Fig. 2). In the lower Ems estuary, ammonium concentrations increased with increasing salinity because of net ammonium input from the extensive tidal-flat areas.

In the lower estuaries, nitrate concentrations decreased linearly with increasing salinity through mix- 
Table 2. Ranges of ammonium, nitrate, particulate nitrogen (PN), suspended particulate matter (SPM), specific uptake rates of ammonium $\left(V \mathrm{NH}_{4}\right)$ and nitrate $\left(V \mathrm{NO}_{3}\right)$, median dark/light $(\mathrm{D} / \mathrm{L})$ uptake ratios of ammonium and nitrate, and median isotopedilution (ID) correction-factors for ammonium (uptake/apparent uptake)

\begin{tabular}{|c|c|c|c|c|c|c|c|c|c|}
\hline Estuary & $\begin{array}{l}\mathrm{NH}_{4} \\
(\mu \mathrm{M})\end{array}$ & $\begin{array}{l}\mathrm{NO}_{3} \\
(\mu \mathrm{M})\end{array}$ & $\begin{array}{c}\text { PN } \\
(\mu \mathrm{M})\end{array}$ & $\begin{array}{c}\text { SPM } \\
\left(\mathrm{mg} \mathrm{l}^{-1}\right)\end{array}$ & $\begin{array}{l}V \mathrm{NH}_{4} \\
\left(\mathrm{~h}^{-1}\right)\end{array}$ & $\begin{array}{l}\mathrm{VNO}_{3} \\
\left(\mathrm{~h}^{-1}\right)\end{array}$ & $\begin{array}{c}\mathrm{D} / \mathrm{L} \\
\left(\mathrm{NH}_{4}\right)\end{array}$ & $\begin{array}{c}\mathrm{D} / \mathrm{L} \\
\left(\mathrm{NO}_{3}\right)\end{array}$ & $\begin{array}{c}\text { ID } \\
\left(\mathrm{NH}_{4}\right)\end{array}$ \\
\hline Ems & $1.0-16$ & $15-285$ & $5.2-240$ & $12-945$ & $0.0003-0.016$ & $0.00009-0.0035$ & 0.61 & 0.39 & 1.026 \\
\hline Scheldt & $0.15-245$ & $47-348$ & $4.5-67$ & $5.9-95$ & $0.007-0.025$ & $0.00013-0.0093$ & 0.45 & 0.51 & 1.015 \\
\hline Loire & $2.0-5.5$ & $4.0-68$ & $3.5-154$ & $14-434$ & $0.004-0.012$ & $0.00030-0.00275$ & 0.48 & 0.22 & 1.046 \\
\hline Gironde & $0.39-1.63$ & $26-160$ & $1.3-213$ & $3.4-1151$ & $0.0005-0.010$ & $0.00025-0.011$ & 0.63 & 0.44 & 1.058 \\
\hline Douro & $0.22-8.1$ & $3.5-93$ & $2.4-7.0$ & $2.3-32$ & $0.0006-0.035$ & $0.00015-0.0096$ & 0.81 & 0.37 & 1.028 \\
\hline Rhine, summer & $3.6-11$ & $4.9-208$ & $1.9-7.5$ & $1.4-17.2$ & $0.002-0.055$ & $0.0001-0.0061$ & 0.86 & 0.15 & 1.007 \\
\hline Rhine, autumn & $2.7-13$ & $14-254$ & $1.7-7.5$ & $3.7-26$ & $0.001-0.058$ & $0.00008-0.0082$ & 0.97 & 1.0 & 1.003 \\
\hline Rhine, spring & $0.20-27$ & $18-336$ & $2.4-9.0$ & $2.0-23$ & $0.0008-0.027$ & $0.00005-0.003$ & 0.77 & 0.43 & 1.006 \\
\hline
\end{tabular}

ing with low-nitrate seawater. Nitrate concentrations in the upper estuaries either increased (Scheldt) or were fairly stable (e.g. Ems, Gironde) as a result of net nitrate input or production.

\section{Nitrogen uptake}

Specific uptake rates of ammonium ( $\left.V \mathrm{NH}_{4}\right)$ and nitrate $\left(\mathrm{VNO}_{3}\right)$ ranged from 0.0003 to $0.058 \mathrm{~h}^{-1}$ and 0.00005 to $0.011 \mathrm{~h}^{-1}$, respectively (Table 2 ). Concentrations of SPM concentrations ranged from a few milligrammes per litre in the Douro and Rhine estuaries to hundreds of milligrammes per litre in the Ems, Loire and Gironde, with the Scheldt displaying intermediate values. Specific uptake rates of ammonium were significantly negatively correlated with concentrations of SPM ( $p<0.0001)$, but the regression explained $<18 \%$ of the variance. There was no significant relationship between the specific uptake rate of nitrate and SPM.

Uptake rates of ammonium ranged from 0.005 to $1.56 \mu \mathrm{mol} \mathrm{N}{ }^{-1} \mathrm{~h}^{-1}$, and differed significantly between estuaries $(F=7.4 ; \mathrm{p}<0.0001)$, within estuaries $(F=$ 33.2; $\mathrm{p}<0.0001$ ), and as a function of light availability $(F=8.4 ; p=0.005)$. Between-estuaries differences were related to salinity (interaction term: $F=6.6$; $p<$ $0.0001)$. A post-hoc Tukey-Kramer test revealed that uptake rates in the Gironde estuary were significantly lower than in the Scheldt and Loire estuaries. Ammonjum uptake rates in the Rhine estuary during summer were significantly higher than during spring and autumn $(F=5.8 ; p=0.005)$. Median dark/light uptake ratios varicd from 0.45 to 0.48 in the Schcldt and Loire estuaries to close to 1 during the Rhine autumn cruise (Table 2). Median correction factors for isotope dilution, based on the model of Kanda et al. (1987), ranged from 1.003 in the Rhine estuary to 1.058 in the Gironde estuary (Table 2). The addition of antibiotic inhibitor reduced ammonium uptake rates in the Loire estuary on average by $93 \%(F=21.3 ; \mathrm{p}=0.00017)$, indicating that isotopic exchange between adsorbed ammonium and added ${ }^{15} \mathrm{NH}_{4}$ was not significant and that most of the (dark) uptake was effected by bacteria.

Uptake rates of nitrate ranged from 0.00025 to


estuaries $(F=18.7 ; \mathrm{p}<0.0001)$, within estuaries $(F=$ 31.2; $\mathrm{p}<0.0001$ ) and as a function of light availability $(F=34.3 ; \mathrm{p}<0.0001)$. Between-estuaries differences were related to salinity (interaction term: $F=2.8 ; \mathrm{p}=$ 0.004). A post-hoc Tukey-Kramer test revealed nitrate uptake rates in the Douro and Rhine estuaries to be significantly lower than in the other estuaries. Nitrate uptake rates in the Rhine varied with season $(F=14.1$; $p<0.0001)$ and light $(F=4.1 ; p=0.05)$ and their interaction $(F=3.3 ; p=0.044)$. Nitrate uptake rates in spring were significantly lower than in summer and autumn. Median dark/light ratios of nitrate uptake were generally lower than those of ammonium, and varied between 0.22 in the Loire estuary and 1 during the Rhine autumn cruise (Table 2). Nitrate uptake rates did not require a correction for isotope dilution because all ratios of corrected to uncorrected uptake were $<1.0001$.

Maximum ammonium uptake occurred in the middle part of the Ems, Gironde and Douro estuaries and the upper part of the Scheldt, Loire and Gironde estuaries (Fig. 2). Nitrate uptake was relatively high in the riverine or upper parts of the Ems, Loire and Gironde and the middle part of the Scheldt and Gironde estuaries. Absolute ammonium and nitrate uptake rates were significantly positively correlated with their concentrations ( $p=0.0002$ and $<0.0001$, respectively), but the regressions explained less than 10 and $22 \%$ of the valiance, respectively. Ammonium and nitrate uptake rates were negatively related with the depth of the euphotic zone $(p<0.0001)$, with coefficients of determination of 0.35 and 0.44 , respectively (Fig. 3).

The relative utilization (U) of ammonium and nitrate is usually expressed in terms of the relative prefer- 

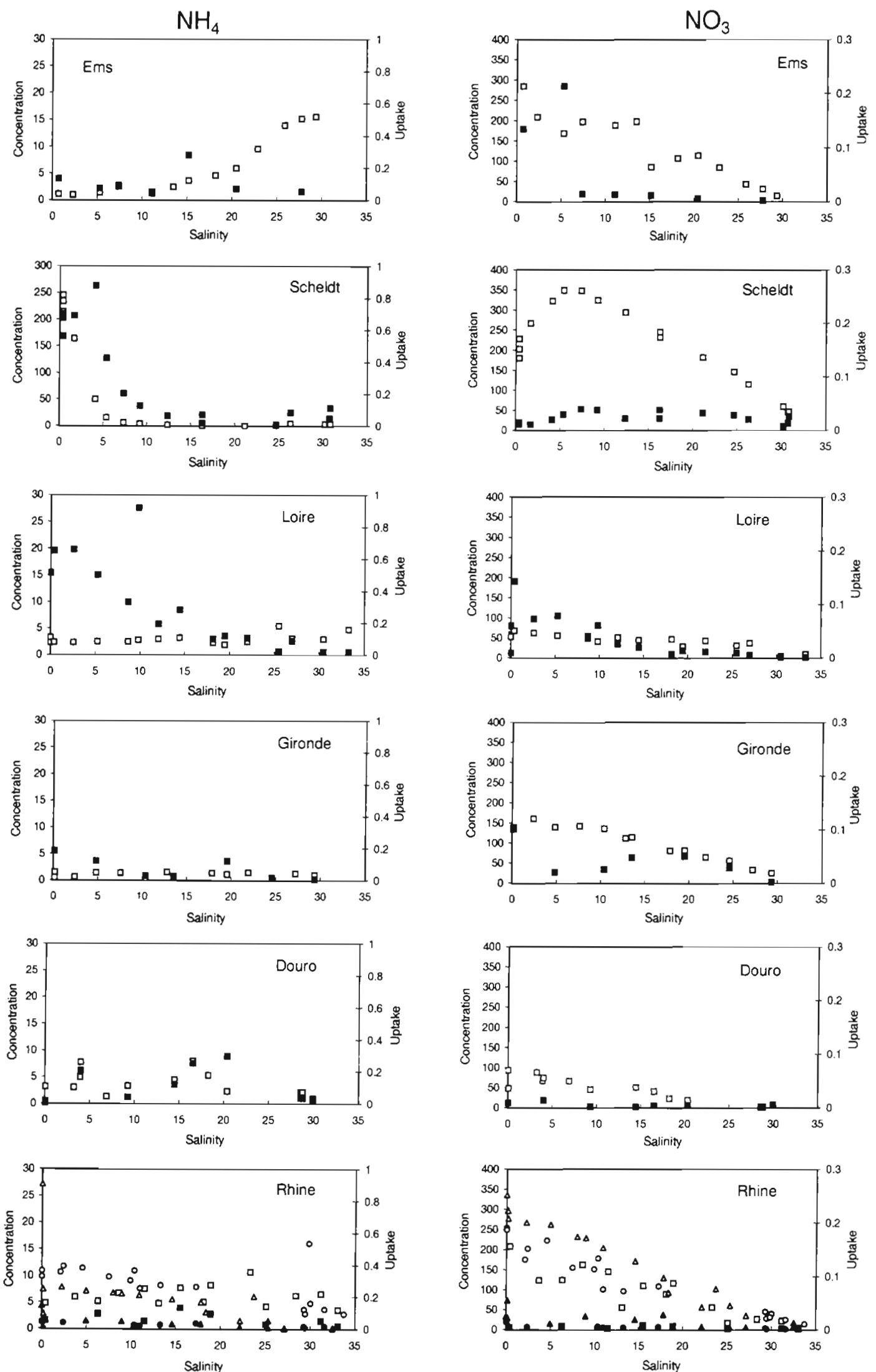


Scheldt, Loire, Gironde, Douro and Rhine estuaries. $(\square, \boldsymbol{\square})$ : $\operatorname{Summer}(\Delta, \mathbf{\Delta})$ : $\operatorname{spring} ;(0, \bullet)$ : autumn 


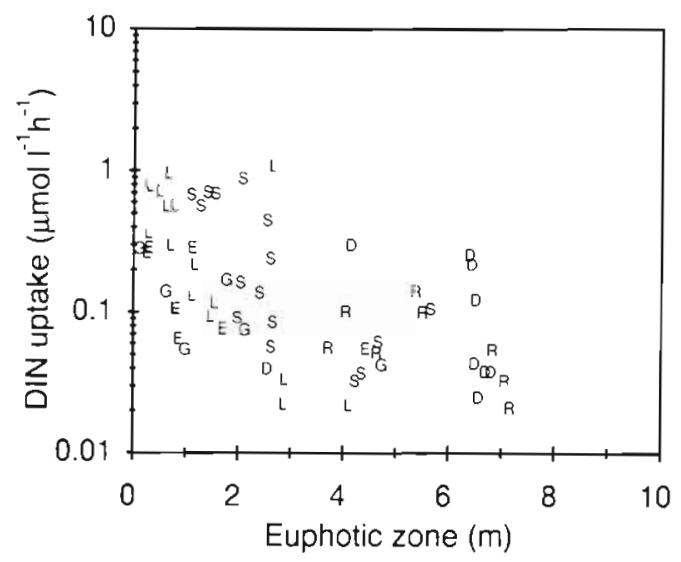

Fig. 3. Nitrogen uptake as a function of depth of euphotic zone. E: Ems estuary; S: Scheldt Estuary; L: Loire Estuary;

G: Gironde Estuary; D: Douro estuary; R: Rhine Estuary

ence index (RPI) for nitrate (McCarthy et al. 1977), where

$$
\text { RPI }=\left[U_{\mathrm{NO}_{3}} /\left(U_{\mathrm{NH}_{4}}+U_{\mathrm{NO}_{3}}\right]\right] /\left[\mathrm{NO}_{3} /\left(\mathrm{NO}_{3}+\mathrm{NH}_{4}\right)\right]
$$

A RPI of $<1$ indicates a preference for ammonium. Ammonium was the preferred nitrogen source in all samples $(\mathrm{RPI}<1$; Fig 4$)$. Only at very low levels of ammonium ( $\leqslant 2 \mu \mathrm{M}$ ) did nitrate uptake become important.

\section{Nitrogen turnover}

Turnover time of particulate nitrogen (PN divided by total DIN uptake) ranged from 0.7 to $31 \mathrm{~d}$ and differed significantly different between estuaries $(F=5.3 ; \mathrm{p}=$ 0.0004 ). The turnover of particulate nitrogen was similar or more rapid (Scheldt estuary) than the estuarine residence time of water (Fig. 5). Turnover time of ammonium and nitrate (concentration divided by uptake rate) varied between 0.1 and $27 \mathrm{~d}$ and 19 and $2160 \mathrm{~d}$, respectively; that of nitrate varied significantly as a function of estuary $(F=4.8 ; p=0.001)$. Nitrate turnover was slower than the estuarine residence time of water, whereas ammonium turnover was more rapid than (Ems, Scheldt, Loire, Gironde) or similar to (Douro, Rhine) estuarine-water residence time (Fig. 5).

\section{DISCUSSION}

\section{Nitrogen uptake}

Specific uptake rates covered a very wide range (Table 2), as they are affected by the amount of detrital, non-living particulate nitrogen (Dugdale \& Wilkin-
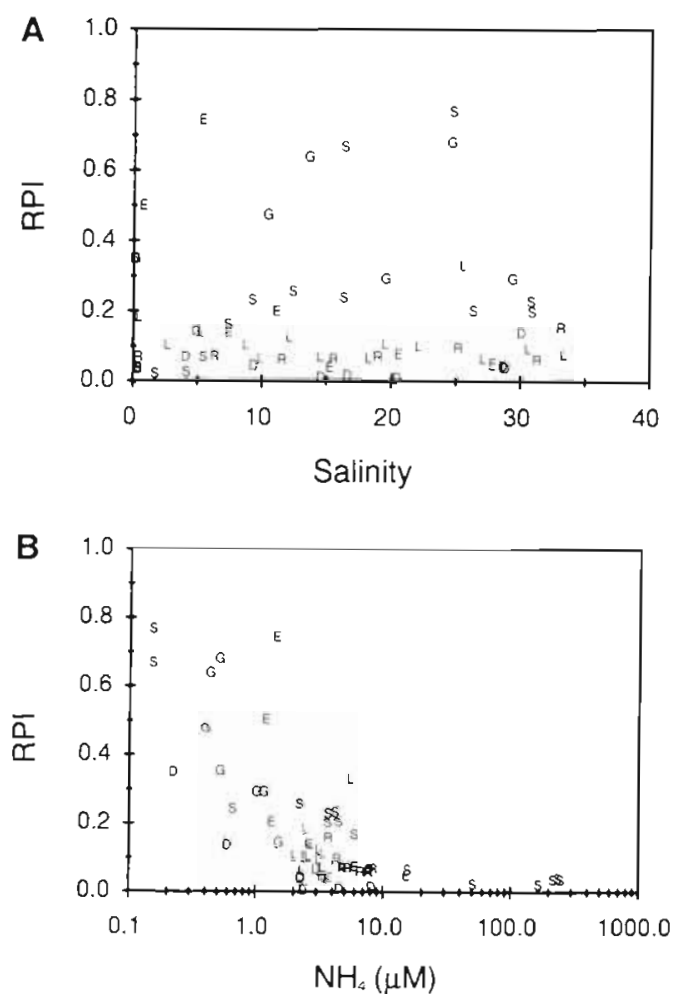

Fig. 4. (A) Relative preferential index, RPI $\left[\mathrm{U}_{\mathrm{NO}_{3}} /\left(\mathrm{U}_{\mathrm{NH}_{4}}+\mathrm{U}_{\mathrm{NO}_{3}}\right)\right] /$ $\left[\mathrm{NO}_{3} /\left(\mathrm{NO}_{3}+\mathrm{NH}_{4}\right)\right]$ as a function of salinity. (B) RPI as a function of ammonium concentration. Abbreviations as in Fig. 3

son 1986). The quantity of SPM as well as the relative contribution of detrital nitrogen to the total particulate nitrogen pool varied significantly between estuaries (Table 2, Fig. 6). The range of specific uptake rates is best understood in the context of 2 components of particulate matter: an active component with a $\mathrm{C} / \mathrm{N}$ molar ratio of 7 (i.e. a nitrogen content of $6.6 \mathrm{wt} \%$ ) and a detrital pool with no nitrogen uptake. Clearly, this 2component model is highly simplistic, but it is consistent with extensive physical mixing of resuspended, detrital and biological particles by tidal currents. Nonlinear regression of the mixing curve revealed a specific uptake of $0.02 \pm 0.002 \mathrm{~h}^{-1}$ for the active pool and a nitrogen content of $0.27 \pm 0.04 \mathrm{wt} \% \mathrm{~N}$ for the detrital pool. These values are reasonable estimates (Middelburg \& Nieuwenhuize 1998. Underwood \& Kromkamp 1999), and the 2-component model is therefore consistent with a rapid increase of specific uptake rates connected with the presence of a small active pool of algae un bacieria.

The uptake rates of DIN recorded during the summer in the investigated estuaries are similar to those observed in the Delaware estuary (Pennock 1987), and Chesapeake Bay (McCarthy et. al. 1977. Bronk et al. 1998). However, they are lower than those observed in the Carmans River estuary (Carpenter \& Dunham 

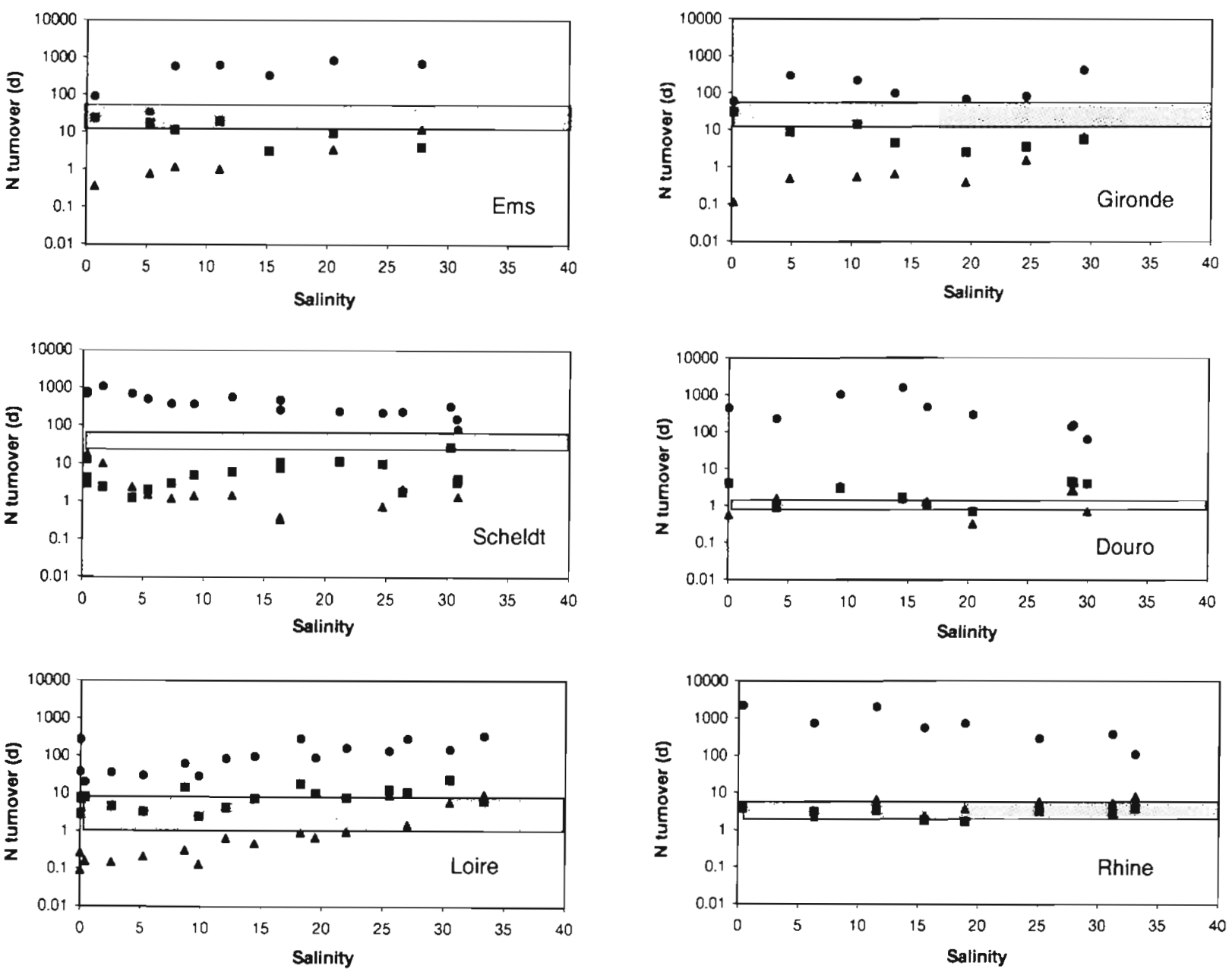

Fig. 5. Turnover of nitrate ( time range of respective estuarine systems

1985), the Neuse River estuary (Boyer et al. 1994), and Oslo fjord (Paasche \& Kristiansen 1982), where algal blooms developed during summer.

The RPI index for nitrate (McCarthy et al. 1977) is often used to assess the relative use of ammonium and nitrate. The use of the RPI has been criticised, since this complex ratio is difficult to interpret and is rather unprecise because of error propagation (Dortch 1990, Underwood \& Kromkamp 1999). Nevertheless, this ratio is useful for comparisons between estuaries. The preferential uptake of ammonium over nitrate (RPI $<1$; Fig. 4) is consistent with the results of most other studies (for a recent review see Underwood \& Kromkamp 1999). In the Delaware estuary, Pennock (1987) observed an increasing contribution of nitrate to total nitrogen uptake with increasing salinity, and Boyer et al. (1994) reported an increase in RPI with increasing salinity in the Neuse River estuary; however, such salinity-dependence would not appear to be a general characteristic of tidal estuaries (Fig. 4). Although all



Fig. 6. Specific uptake rate of ammonium as a funtion of nitrogen content of particulate nitrogen. Regression lines (continuous line: best-fit; dashed lines: 95\% confidence intervals) based on the mixing of an inert detrital pool $(0.27 \pm 0.04 \mathrm{wt} \%$ $\mathrm{N}$, no uptake) and an active pool (6.6 wt\% N, specific uptake of $0.02 \pm 0.002 \mathrm{~h}^{-1}$ ). Abbreviations as in Fig. 3 
RPI values were $<1$ and ammonium was always the preferred inorganic nitrogen source, this preference was less strong when ammonium was $\$ 2 \mu M$, as observed earlier by McCarthy et al. (1977), Paasche \& Kristiansen (1982), Pennock (1987) and Carpenter \& Dunham (1985).

A number of studies have shown that transfer of DIN to the PN pool is not only effected by phytoplankton, but that a (heterotrophic) bacterial component also plays a part (e.g. Wheeler \& Kirchman 1986, Hoch \& Kirchman 1995). It is likely that this is also the case in the estuaries investigated in the present study: (1) The significant enhancement of nitrate and ammonium uptake in the light relative to the dark (Table 2) indicates a significant phytoplankton contribution. (2) Bacteria account for the majority of the ammonium uptake in the dark, at least in the Loire estuary, since addition of an antibiotic resulted in almost complete cessation of uptake (93\%). (3) In these turbid, nitrogen-rich estuaries light limits primary production (Heip et al. 1995, Kromkamp \& Peene 1995, Irigoien \& Castel 1997), and since the depths of these estuaries are similar, nitrogen uptake rates by algae would be expected to increase with increasing depth of the euphotic zone (Kromkamp \& Peene 1995). However, in our study areas nitrogen uptake rates were negatively correlated with the depth of the euphotic zone (Fig. 3). Partitioning algal and microbial DIN assimilation in turbid estuarine systems is difficult: size-partitioning is not feasible because of the high concentrations of SPM that clog collection-filters and the tight association of bacteria with these particles (Heip et al. 1995). Application of bacterial or algal inhibitors might be useful (Wheeler \& Kirchman 1986, and present study), but could be hampered by the specificity of the inhibitor (Oremland \& Capone 1988) Moreover, bacterial $N$ demand may be met by dissolved free amino acids, as observed in the Delaware estuary and Chesapeake Bay (Kirchman 1994, Hoch \& Kirchman 1995)

\section{Nitrogen turnover}

In considering nitrogen turnover it is important to distinguish between estimates based on ${ }^{15} \mathrm{~N}$-tracer experiments restricted to the transfer from DIN to SPM, and estimates derived from mass-balance studies or ecosystem models for the entire ecosystem (including the sediments, ivitrogen iurnover times based on the latter approach are mainly governed by denitrification and sediment burial (Nixon et al. 1996): they reflect ritrogen tunnover in relation to external losses. Nitrogen turnover times based on ${ }^{15} \mathrm{~N}$-tracer experiments clearly do not cover such external losses: they reflect the dynamics of assimilation processes within the estuary. It is therefore useful to compare turnover rates with the residence time of water in the estuaries (Fig. 5). Nitrogen turnover times that are much longer than the water residence time imply: (1) that particulate nitrogen will not accumulate in the estuarine system or be extensively modified during transport, and (2) that DIN is not limiting nitrogen uptake and is not consumed to a significant extent by assimilation processes. Conversely, nitrogen turnover times shorter than the water residence time imply (1) extensive modification of particulate matter, (2) possible nitrogen limitation of primary or bacterial production and (3) a close coupling of production and consumption processes.

Nitrate turnover times related to assimilation are always longer and usually 1 order of magnitude higher than the residence time of water in these estuaries (Fig. 5). Nitrate assimilation does not influence its distribution since it is present in high ambient concentrations (Fig. 2). Most of the nitrate entering or produced in these estuaries flushes through them and is exported to the sea, unless a significant part of the dissolved nitrate is lost to denitrification and/or burial in the sediments. The turnover times for ammonium are shorter than the residence times of water in well-mixed estuaries (Scheldt, Loire, Gironde and Ems estuaries), and are similar to the residence time of water in river-dominated, salt-stratified estuaries (Douro and Rhine). Ammonium is consequently efficiently recycled within these estuaries, as observed in other regions; e.g. Chesapeake Bay (Fisher et al. 1992), Oslo Fjord (Paasche \& Kristiansen 1982), Carmans River estuary (Carpenter \& Dunham 1985). The total particulate nitrogen pool has a turnover time similar to or shorter (Scheldt estuary) than that of the residence time of water, and particles are consequently extensively modified during transit through the estuary.

\section{Nitrogen cycling in heterotrophic estuaries}

Most estuaries are heterotrophic, i.e. respiration dominates over production (Heip et al. 1995, Gattuso et al. 1998). Heterotrophic estuaries are characterised by a bacterial production that is higher than primary production (Relexans et al. 1988, Findlay et al. 1991, Hoch \& Kirchman 1993, Goossen et al. 1997), high organic loading (Heip et al. 1995), high degree of saturation and effluxes of carbon dioxide (Frankignoulle et al. i996, i998j, reiease of greennouse gases juickeiis 1998) and extensive denitrification (Nixon et al. 1996. Trimmer et al. 1998). In heterotrophic systems organic carbon-cycling controls nitrogen-cycling rather than the other way round (Smith et al. 1989).

In a cross-system comparison study, Heip et al. (1995) recognised 2 different types of heterotrophic 
estuaries, based on a primary production level of $160 \mathrm{~g}$ $\mathrm{C} \mathrm{m}^{-2} \mathrm{yr}^{-1}$. The high-production type (above this level) displayed a significant relationship between primary production and net organic input (calculated as the difference between respiration and primary production of the system). The recycling efficiency of nitrogen in such high-production systems was estimated as between 0.7 and 0.8 (per step in the production-consumption cycle), implying a 3-to 4-fold re-utilization of nitrogen entering such estuaries. The low-production type ( $<160 \mathrm{~g} \mathrm{C} \mathrm{m}^{-2} \mathrm{yr}^{-1}$ ) exhibited no correlation between primary production and net organic input because of light limitation of primary production. Heip et al. (1995) were not able to assess the recycling efficiency of nitrogen in these latter turbid systems. The results of our study clearly indicate that ammonium and particulate organic nitrogen entering these turbid estuaries are also efficiently recycled (Fig. 5), but that nitrogen assimilation is effected not only by algal, but also by bacterial production.

This efficient recycling of particulate organic nitrogen in heterotrophic estuaries has important ecological and biogeochemical consequences. Any riverine or terrestrial organic matter transferred through the estuary is extensively modified by microbial respiration and production processes. Riverine particulate nitrogen can consequently constitute a significant source of nitrogen to estuarine systems (Mayer et al. 1998). Heterotrophic micro-organisms assimilate DIN, and can thus contribute significant quantities of organic nitrogen to estuarine ecosystems (Caraco et al. 1998). Microbial nitrogen assimilation can also enrich the particulate nitrogen fraction with ${ }^{15} \mathrm{~N}$ (Caraco et al. 1998, Mayer et al. 1998, Middelburg \& Nieuwenhuize 1998), and consequently complicate interpretations of estuarine food webs based on stable isotope studies. Bacterial assimilation of nitrogen lowers the $\mathrm{C} / \mathrm{N}$ ratio and enhances the nutritional value of particulate matter, which is an important food source for pelagic and benthic consumers.

To conclude, uptake patterns of ammonium and nitrate in turbid estuaries along the European Atlantic coast are similar to those reported for the Atlantic coast estuaries of the USA (e.g. McCarthy et al. 1977, Garside 1981, Pennock 1987, Fisher et al. 1992, Boyer et al. 1994), with ammonium being preferred over nitrate, and significant DIN uptake in the dark, most of which is attributable to bacteria.

Acknowledgements. We thank the captains and crews of the RVs 'Luctor', 'Belgica' and 'Mestre Costeiro' for their hospitality, and our BIOGEST colleagues for sharing water samples and providing a pleasant, stimulating scientific climate. We thank Peter Herman, Karline Soetaert, Jacco Kromkamp, Michel Frankignoulle and 4 anonymous reviewers for constructive remarks. This is contribution no. 114 of the project
BIOGEST to the EU-supported ELOISE programme (ENV4CT96-0213) and publication no. 2580 of The Netherlands Institute of Ecology, Yerseke.

\section{LITERATURE CITED}

Boyer JN, Stanley DW, Christian RR (1994) Dynamics of $\mathrm{NH}_{4}{ }^{+}$ and $\mathrm{NO}_{3}{ }^{-}$uptake in the water column of the Neuse River estuary, North Carolina. Estuaries 17:361-371

Bronk DA, Glibert PM, Malone TC, Banahan S, Sahlsten E (1998) Inorganic and organic nitrogen cycling in Chesapeake Bay: autotrophic versus heterotrophic processes and relationships to carbon flux. Aquat Microb Ecol 15: $177-189$

Caraco NF, Lampman $G$, Cole JJ, Limburg KE, Pace ML, Fisher D (1998) Microbial assimilation of DIN in a nitrogen rich estuary: implications for food quality and isotope studies. Mar Ecol Prog Ser 167:59-71

Carpenter EJ, Dunham S (1985) Nitrogenous nutrient uptake, primary production, and species composition of phytoplankton in the Carmans River estuary, Long Island, New York. Limnol Oceanogr 30:513-526

Dortch Q (1990) The interaction between ammonium and nitrate uptake in phytoplankton. Mar Ecol Prog Ser 61: 183-201

Dugdale RC, Wilkerson FP (1986) The use of ${ }^{15} \mathrm{~N}$ to measure nitrogen uptake in eutrophic oceans; experimental considerations. Limnol Oceanogr 31:673-689

Findlay S, Pace ML, Lints D, Cole JJ, Caraco NF, Peierls B (1991) Weak coupling of bacterial and algal production in a heterotrophic ecosystem: the Hudson River estuary. Limnol Oceanogr 36:268-278

Fisher TR, Peele ER, Ammerman JW, Harding LW Jr (1992) Nutrient limitation of phytoplankton in Chesapeake Bay. Mar Ecol Prog Ser 82:121-128

Frankignoulle $\mathrm{M}$, Bourge I, Wollast R (1996) Atmospheric $\mathrm{CO}_{2}$ fluxes in a highly polluted estuary (the Scheldt). Limnol Oceanogr 41:365-369

Frankignoulle $M_{1}$ Abril $G$, Borges A, Bourge I, Canon C, Delille B, Libert E, Théate JM (1998) Carbon dioxide emission from European estuaries. Science 282:434-436

Garside C (1981) Nitrate and ammonium uptake in the apex of the New York Bight. Limnol Oceanogr 26:731-739

Gattuso JP, Frankignoulle M, Wollast R (1998) Carbon and carbonate metabolism in coastal aquatic ecosystems. Annu Rev Ecol Syst 29:405-434

Goossen NK, van Rijswijk P, Kromkamp J, Peene J (1997) Regulation of annual variation in heterotrophic bacterial production in the Schelde estuary. Aquat Microb Ecol 12: $223-232$

Heip CHR, Herman PMJ (1995) Major biological processes in European tidal estuaries. Hydrobiologia 311:1-7

Heip CHR, Goosen NK, Herman PMJ, Kromkamp J, Middelburg JJ, Soetaert K (1995) Production and consumption of biological particles in temperate tidal estuaries. Oceanogr Mar Biol Annu Rev 33:1-150

Hoch MP, Kirchman DL (1993) Seasonal and inter-annual variability in bacterial biomass and production in a temperate estuary. Mar Ecol Prog Ser 98:283-296

Hoch MP, Kirchman DL (1995) Ammonium uptake by heterotrophic bacteria in the Delaware estuary and adjacent coastal waters. Limnol Oceanogr 40:886-897

Howarth RW, Billen G, Swaney D, Townsend A, Jaworski N, Lajtha $K$, Downing JA, Elmgren $R$, Caraco $N$, Jordan $T$, Berendse $F$, Freney J, Kudeyarov V, Murdoch P, Zhu ZL (1996) Regional nitrogen budgets and riverine $N$ and $P$ 
fluxes for the drainages to the North Atlantic Ocean: natural and human influences. Biogeochemistry 35:75-139

Irigoien X, Castel JC (1997) Light limitation and distribution of chlorophyll pigments in a highly turbid estuary: the Gironde (SW France). Estuar Coast Shelf Sci 44:507-517

Jickells TD (1998) Nutrient biogeochemistry of the coastal zone. Science 281:217-222

Kanda J, Laws EA, Saino T, Hattori A (1987) An evaluation of isotope dilution from conventional data sets of ${ }^{15} \mathrm{~N}$ uptake experiments. J Plankton Res 9:79-90

Kirchman DL (1994) The uptake of inorganic nutrients by heterotrophic bacteria. Microb Ecol 28:255-271

Kromkamp J, Peene J (1995) Possibility of net phytoplankton primary production in the turbid Schelde Estuary (SW Netherlands). Mar Ecol Prog Ser 121:249-259

Mayer LM, Keil RG, Macko SA, Joye SB, Ruttenberg KC. Aller RC (1998) Importance of suspended particulates in riverine delivery of bioavailable nitrogen to coastal zones. Global Biogeoch. Cycles 12:573-579

McCarthy JJ, Taylor RW, Taft JL (1977) Nitrogenous nutrition of plankton of the Chesapeake Bay. 1. Nutrient availability and phytoplankton preference. Limnol Oceanogr 223: 996-1911

Middelburg JJ, Nieuwenhuize J (1998) Carbon and nitrogen stable isotopes in suspended matter and sediments from the Schelde Estuary. Mar Chem 60:217-225

Nieuwenhuize J, Maas YEM, Middelburg JJ (1994) Rapid analysis of organic carbon and nitrogen in particulate materials. Mar Chem 44:217-224

Nixon SW, Ammerman JW, Atkinson LP, Berounsky VM, Billen G, Boicourt WC, Boynton WR, Church TM, DiToro DM, Elmgren R. Garber JH, Giblin AE, Jahnke RA, Owens NJP, Pilson MEQ, Seitzinger SP (1996) The fate of nitrogen and phosphorus at the land-sea margin of the North Atlantic Ocean. Biogeochemistry 35:141-180

Oremland RS, Capone DG (1988) Use of specific inhibitors in biogeochemistry and microbial ecology. Adv Microb Ecol $10: 285-383$

Editorial responsibility: Otto Kinne (Editor), Oldendorf/Luhe, Germany
Paasche E, Kristiansen S (1982) Nitrogen nutrition of phytoplankton in the Oslo fjord. Estuar Coast Shelf Sci 14 $237-249$

Pennock JR (1987) Temporal and spatial variability in phytoplankton ammonium and nitrate uptake in Delaware estuary. Estuar Coast Shelf Sci 24:841-857

Relexans JC, Meybeck M, Billen G, Burgeaille M, Etcheber H, Somville M (1988) Algal and bacterial abundance, production and specific growth rate in the Loire estuary. Estuar Coast Shelf Sci 27:625-644

Seitzinger SB, Kroeze C (1998) Global distribution of nitrous oxide production and $\mathrm{N}$ inputs in freshwater and coastal marine ecosystems. Global Biogeochem Cycles 12:93-114

Shaw PJ, Purdie DA, de Frietas PS, Rees, AP, Joint I (1998) Nutrient uptake in a highly turbid estuary the Humber, United Kingdom) and adjacent coastal waters. Estuaries 21:507-51.7

Smith SV, Hollibaugh JT, Dollar SJ, Vink S (1989) Tomales Bay, California: a case for carbon-controlled nitrogen cycling. Limnol Oceanogr 34:37-52

Soetaert K. Herman PMJ (1995) Nitrogen dynamics in the Westerschelde estuary (SW Netherlands) estimated by means of the ecosystem model MOSES. Hydrobiologia $311: 225-246$

Soetaert K, Herman PMJ, Kromkamp J (1994) Living in the twilight: estimating net phytoplankton growth in the Westerschelde estuary (The Netherlands) by means of an ecosystem model (MOSES). J Plankton Res 16:1277-1301

Trimmer M, Nedwell DB, Sivyer DB, Malcolm SJ (1998) Nitrogen fluxes through the lower estuary of the river Great Ouse, England: the role of the bottom sediments. Mar Ecol Prog Ser 163:109-124

Wheeler PA, Kirchman DL (1986) Utilization of inorganic and organic nitrogen by bacteria in marine systems. Limnol Oceanogr 31:998-1009

Underwood GJC, Kromkamp J (1999) Primary production by phytoplankton and microphytobenthos in estuaries. Adv Ecol Res 29:93-153

Submitted: February 22, 1999; Accepted: September 13, 1999 Proofs received from author(s): January 13, 2000 